\title{
DEMOGRAPHIC ENERGY-BALANCED FRAMEWORK FOR SUSTAINABLE URBAN ENVIRONMENTS
}

\author{
Tobias Teich, Mirko Bodach, Matthias Hoffmann, Tim Neumann, Philipp Werler, \\ Tobias Härtel, Sebastian Junghans, Christian Blumhagen
}
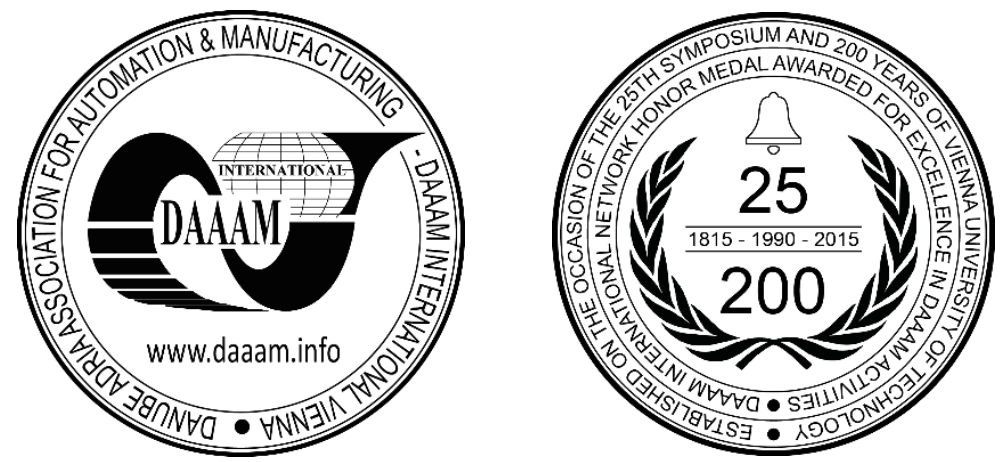

This Publication has to be referred as: Teich, T[obias]; Bodach, M[irko]; Hoffman, M[atthias]; Neumann, T[im]; Werler, P[hilipp] \& Hartel, T[obias] (2017). Demographic Energy-balanced Framework for Sustainable Urban Environments, Proceedings of the 28th DAAAM International Symposium, pp.1044-1050, B. Katalinic (Ed.), Published by DAAAM International, ISBN 978-3-902734-11-2, ISSN 1726-9679, Vienna, Austria

DOI: $10.2507 / 28$ th.daaam.proceedings. 145

\begin{abstract}
The social-political tendency in Germany clearly shows that the integration of issues that ensure affordability and quality of life, such as the use of intelligent options, taking into account demographic aspects, are necessary for sustainable development in order to ensure the viability of housing. The starting point is defined in the problem of the hitherto separated view on the areas of human, health and energy with the demographic change of the people in a district.

The goal of the project is therefore to enable a demographically oriented operationalization of these concepts for the attainability of a "sustainable livelihood" through the integrated and multidisciplinary consideration of the existing developments. The main objectives are: to develop a generic networking model for the integration of the partial models of an original independent competence cluster; to use previously unused potentials from the currently missing integration of different perspectives. A demonstrable improvement of the energetic situation is to be achieved by a systemic integration. In particular, the impact of demographic effects on people as tenants as well as integratable solutions with regard to technological infrastructure and feedback possibilities on thermal, electrical and information technology components are analysed.
\end{abstract}

Keywords: networking; ubiquitous; sustainability; integration; demography

\section{Introduction}

To enable a demographic-oriented operationalization of concepts for the accessibility of a Sustainable Way of Living through the integrated and multidisciplinary consideration of previous developments identified gaps should be concluded with the project in the form of an operationalizable framework (figure 1). Living or "housing" in a building is a basic need of people in a modern civilisation and the providing of housing is a fundamental right. However, the financing of these essential factors must still be possible in 20 to 30 years. The urban environment, with its neighbourhoods of buildings and infrastructure, is one of the most important drivers of climate change. At the same time it forms the basis for a sustainable life. (see further in [1]) 


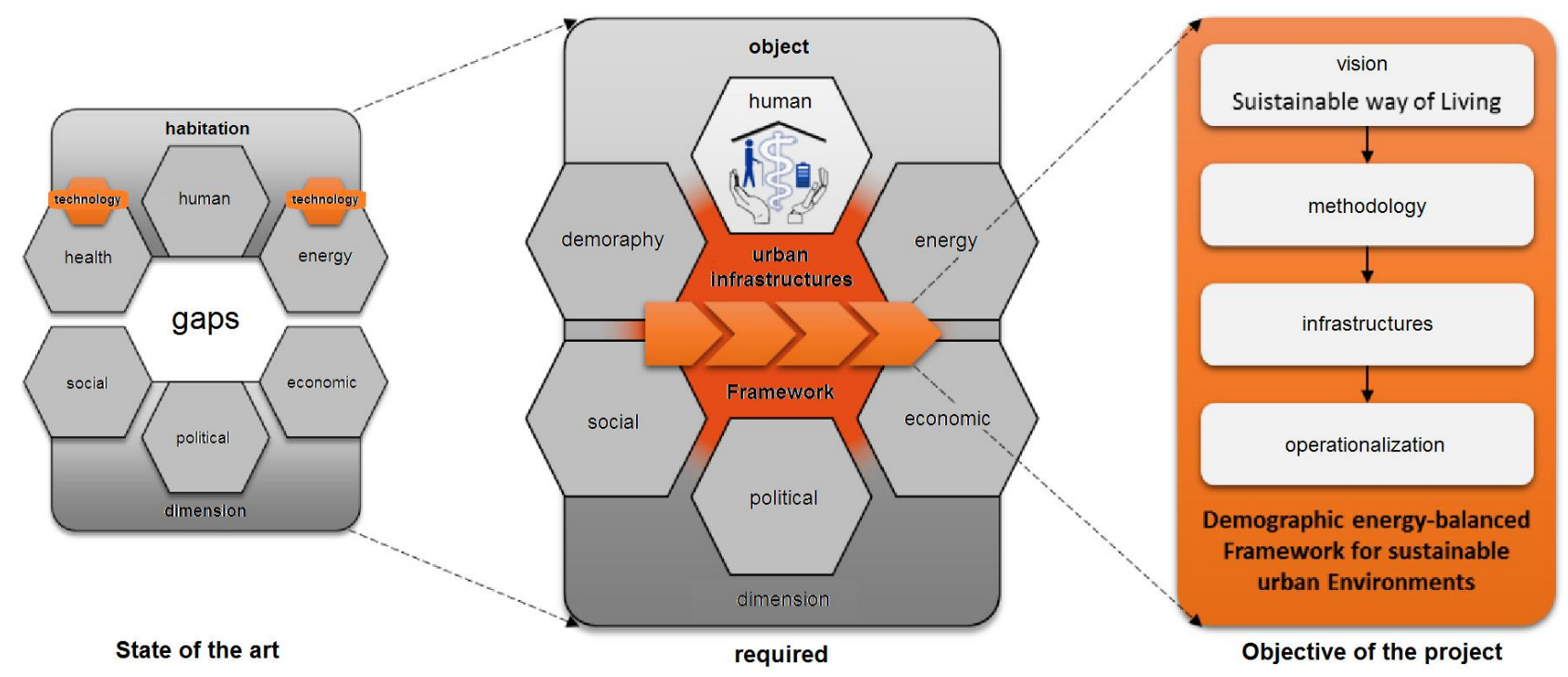

Fig. 1. Objective of the project

The demographic development and its serious impacts are of central importance for future, generational concepts of self-determined life, especially in priority regions such as Zwickau (see figure 2). The Zwickau region is a demographic focus region in nationwide comparison. Due to the ongoing demographic change and the aging society, resulting problems will also affect other municipalities. The resulting demographic stress field is increasingly aggravated by the negative development of the relationship between persons making the supply and benefit recipients in the socio-economic context (persons with a social security obligation / the recipient of social benefits, and in particular pension payments). The ratio is currently about three to one [2]. It will deteriorate drastically because of the demographic development. In less than 20 years it will be about one to one [3]. This imbalance consequently leads to a reduction in the income of pensioners.

In the same period there is a development of pensions in eastern Germany from an average of EUR 879 to 530 which shows how dramatically the situation of affordable rents, health and energy costs will develop [4]. Thus, the old age poverty is one of the greatest risks of the future for the region. This illustrates the enormous societal importance of the issue for Germany and manifests the demand situation for the problem beyond the region of Zwickau, too [5]. From the global climatic as well as the regional demographic and therefore necessary infrastructural change results not only the demand for partial and complete restructuring of the health service and in particular the outpatient care, but also the technical approaches in thermal and electrotechnical supply systems.

A Sustainable Way of Living can only be achieved with the help of novel concepts and systems, which are defined and planned at district level. The personal requirements of the residents for individual care cause an increasingly frequented form of media supply in the fields of energy and health care. These requirements must be countered with a redefinition of application concepts for technical building equipment and integration across hierarchical levels. At the moment, there is a steady development and optimization of partial models of individual competence clusters, e.g. care in medicine, medicine and energy supply and ambient-based life.

However, the transfer into a generic networking model with holistic methods for the integration of these competence clusters has been completely missing (figure 3). In this way, only isolated solutions result, although the objective of integration has been formulated in many applications. Roll-outs are practically not observable after the end of the funding period due to unproven profitability. The necessary realization of an interdisciplinary interaction and functional integration fails due to lack of integration or interoperability interest or restricted possibilities of the different branches, manufacturers or products. As a university of applied sciences, the connection between research and teaching is essential for the Westsächsische Hochschule Zwickau (WHZ).

The development of the student enrolments and, in particular, the notable negative trend of the MINT quota (Mathematics, computer science, natural sciences and technology) require new and innovative study contents for a successful continuation of the university landscape. Particular attention must be paid to the interdisciplinary combination of different technical fields currently required by the market. Energy efficiency and health as cross-cutting issues offer such a possibility. 


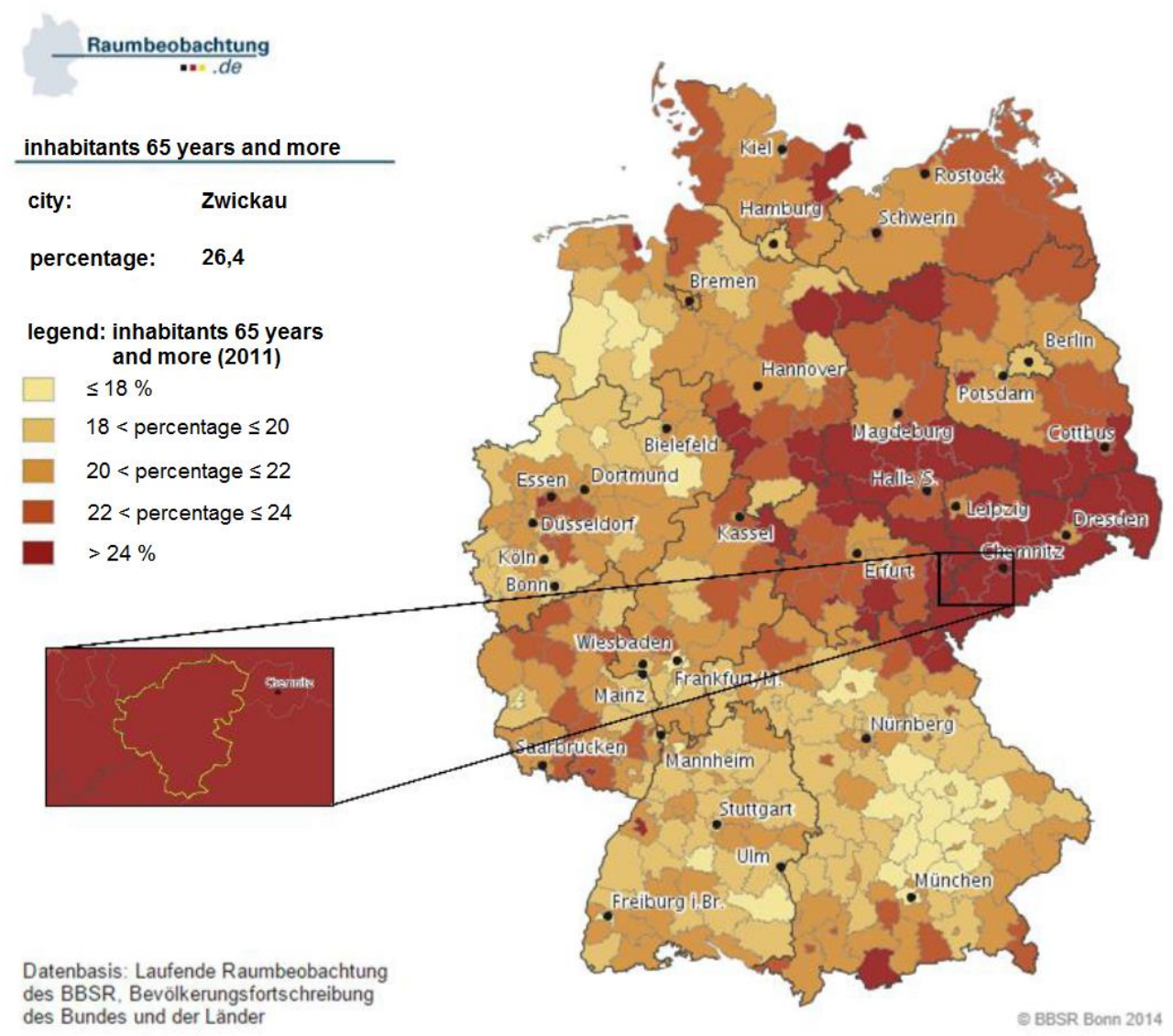

Fig. 2. age structure of Germany in 2011

\section{Specific objectives of the project}

A generic network model is to be developed for the integration of the partial models of an original, independent competence cluster in order to use previously unused potentials resulting from the currently missing integration of different perspectives. With the help of the project results a demonstrable improvement of the energetic situation is to be achieved by systemic integration. In particular, the influence of demographic effects on people as tenants as well as integrative solutions with regard to technological infrastructure and feedback possibilities on thermal, electrical and information technology components are analyzed. This approach is clearly distinguished from the widespread singular technical approaches by creating superior technical procedures and integrating networks on the infrastructural, energetic and organizational level. This results in the possibility to synthesise novel, cross-sectoral potentials for increasing the efficiency in networked systems - both for people as tenants in their homes, as well as for the lessors, such as thermal and electrical supply at neighbourhood levels. The project is supported by a competence center for energetic and health care services, which was financed by the city of Zwickau and the Sächsische Aufbaubank on the basis of the results of the previous research groups and was built in 2015 and 2016. It is used to transfer results in the direction of large-scale tenants, healthcare providers and, in particular, citizens as an information and counseling center.

\section{Preliminary work}

Various completed research projects formed the methodological and organizational basis for the intended project. The experiences of these projects, the cooperation of the project management in the panel on climate issues of the city of Zwickau as well as in the Advisory Board "AlterLeben" of the Association of Saxon Housing Cooperatives (Wohnungsbaugenossenschaften e.V. - VSWG) and numerous other preparatory works clearly show that in the future only cooperative structures as well as interoperability and intersectoral business processes including the required Systems can lead to comprehensive and sustainable solutions. (see in [6] and [7]) The choice of the cooperating partners involved in the project illustrates the regional strength and the user-friendliness of the applicant's past projects in the research area. In the project described here, this existing network is to be used and expanded accordingly. In the "Low Energy Living" project (sponsored with 1.7 million euro by the European Social Fund, ESF) the possibilities for sustainable energy saving were examined using intelligent building system technology in the practical environment of municipal housing construction. (see further in [8])

The main focus and the results to be expected are listed below: 


\begin{tabular}{|c|c|}
\hline main focus & objective / result \\
\hline $\begin{array}{l}\text { Framework zum Sustainable } \\
\text { Way of Living }\end{array}$ & $\begin{array}{l}\text { Scientific framework for the operationalization of a generic networking model for the } \\
\text { realization of an adaptive network with the purpose of securing the Sustainable Way of } \\
\text { Living }\end{array}$ \\
\hline ecoBSC & $\begin{array}{l}\text { Instrument for large-scale tenants to support the (investment) decisions of sustainable } \\
\text { neighbourhood development within an integrated urban development concept as well as } \\
\text { the assessment of the energy and demographic situation of jointly supplied } \\
\text { neighbourhoods and the derivation of relevant measures }\end{array}$ \\
\hline $\begin{array}{l}\mathrm{ADL} \text { in the district / } \\
\text { neighbourhood }\end{array}$ & $\begin{array}{l}\text { Quartier-oriented further development of the sensor-assisted detection of relevant } \\
\text { activities of daily life (ADL) taking into account demographic aspects as well as billing } \\
\text { event-driven health services }\end{array}$ \\
\hline $\begin{array}{l}\text { Multidisciplinary } \\
\text { interoperability }\end{array}$ & $\begin{array}{l}\text { Model for multidisciplinary information management as well as integration and } \\
\text { enhancement of the interoperability of sensor networks in residential districts to the } \\
\text { interdisciplinary and manufacturer-independent information exchange }\end{array}$ \\
\hline energy accounting & $\begin{array}{l}\text { New billing models for the active energy consumption awareness of tenants with a } \\
\text { transparent representation of the tenant's potential for room regulation in the network }\end{array}$ \\
\hline planning methods & $\begin{array}{l}\text { Appropriate technical planning approaches to take account of the future requirements } \\
\text { for an economic and sustainable development of districts }\end{array}$ \\
\hline $\begin{array}{l}\text { Modular swarm-intelligent } \\
\text { network nodes }\end{array}$ & $\begin{array}{l}\text { Involving and intelligently linking decentralized heat storage possibilities and heat } \\
\text { generators as well as increasing energy efficiency with the help of novel heat } \\
\text { distribution variants by using swarm-intelligent network nodes }\end{array}$ \\
\hline network validation & $\begin{array}{l}\text { Generation of forecast algorithms for efficient and domain-spanning energy } \\
\text { management as a result of established requirements profiles taking into account } \\
\text { demographic aspects in the district / neighbourhood }\end{array}$ \\
\hline Transient simulation & $\begin{array}{l}\text { Possibility of control energy participation (consumption and supply), more precise } \\
\text { dimensioning of a modular energy storage device, use of the stationary network } \\
\text { simulation program Cerberus for transient simulation }\end{array}$ \\
\hline scenarios of memory usage & $\begin{array}{l}\text { Efficient operation of the energy storage by taking into account the interactions of all } \\
\text { disciplines and analysis of power-to-heat concepts, determination of the most } \\
\text { economical energy storage, possible combinations and the application method }\end{array}$ \\
\hline Qualification of young scientists & $\begin{array}{l}\text { Transfer of knowledge and results into the teaching concept and content of a MINT } \\
\text { Master's course "Intelligent Building Systems" to increase the MINT rate at the } \\
\text { Westsächsische Hochschule Zwickau (MINT ... Mathematics, computer science, } \\
\text { natural sciences and technology) }\end{array}$ \\
\hline
\end{tabular}

Table 1. Focus and results

The project was successfully completed in October 2012. In Zwickau as well as numerous other cities in Saxony the concept was implemented and achieved a reduction of more than 20 percent primary energy. This led to the definition of further future-oriented research topics. On the one hand, this is the subject of the development and implementation of value-added services on the basis of ubiquitously available and intelligently networked information (ubiquitous infrastructures). For this purpose research projects focussed on health and care management, especially in the Ambient Asissted Living (AAL), are being carried out at the Westsächsische Hochschule Zwickau. On the other hand, energetic potentials were exploited with the use of intelligent building equipment combined with a holistic, inter-branch information infrastructure. The analysis of the energy supply of a district showed tremendous potential for optimization, which could be opened up by networking several different levels of information. Information levels can be, for example, rooms, apartments, entrances, buildings, quarters. Investigations in cooperation with the Brunata-Metrona Group (German market leader for the consumption-based heating and water cost accounting) provide a clear potential for savings through intelligent networking of ubiquitous information of more than $20 \%$ in multi-family houses. (see further in [9])

The project "Ambient Assisted Living in Intelligent Controlled Environments" (A2LICE), which was also funded by the European Social Fund (ESF) with 1.1 million euros, represents the second major line of the project, starting with the results of the Low Energy Living project. The focus of this project was the development of a concept for closing the gap in the medical care chain between in-patient care and self-determined life in the usual environment, leading to a significant improvement in health and care management, self-determination of the elderly and / or handicapped people, in the field of housing construction as well as in commercial and public buildings. The results of the research work so far and the demands resulting from demographic change show that demography and energetics already form a closely interwoven paradigm, which necessarily requires innovative and holistic solution concepts (figure 1). 
Within these two ESF projects as well as in further research work, essential foundations were created in the areas of demography and energy. This can also be demonstrated by further projects which were supported, for example, by the SMWK (Sächsisches Staatsministerium für Wissenschaft und Kunst, engl.: Saxon State Ministry for Science and the Arts): "Combined use of technical and economic instruments to increase energy efficiency in buildings" (March 2009 December 2010), "Ambient Assisted Living in urban house building to overcome demographic problems in health care" (March 2011 - December 2011) or "Ubiquitous infrastructures" (January 2013 - December 2014). The future interdisciplinary consideration of the topic of energy efficiency at the level of energy-assisted shared districts is already taken into account when creating so-called district concepts (KfW432) for the cities of Zwickau, Borna, Riesa, Netzschkau or Oelsnitz/Erzgebirge.

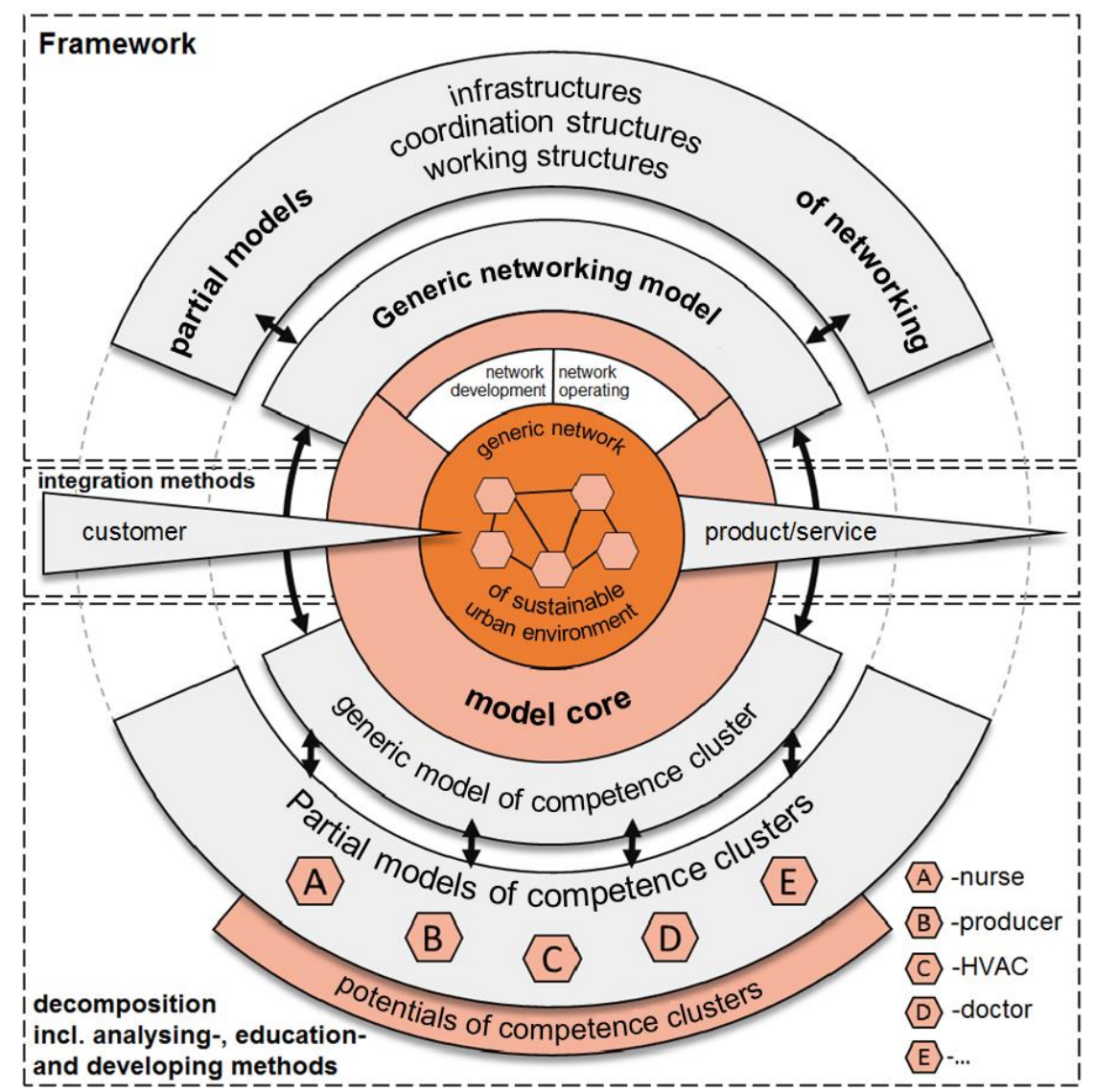

Fig. 3. Presentation of the project objective

Some research work resulted in the publication of patents, in order to provide a basis for the realization of future projects. These include: "Device arrangement for recording, evaluating and influencing heating energy distributions within a building envelope" and "Ubiquitous sensor networking with methods for controlling the heating energy output from local to regional living space structures". In addition to these research activities, which are mainly based on the content, the qualification of young scientists is also promoted. With the help of the co-operative doctoral procedure, scientists have already been successfully supported for their doctorate. These former scientific staff members of the WHZ are in leading positions in the Saxon economy today and strengthen the region of Saxony.

\section{Achievement of objectives and applied operations}

The topics of the project are accompanied by three professorships at the Westsächsische Hochschule Zwickau. The professorship for networked systems in business management is assumed by the project management as well as the content of the demographically motivated subproblems. The professorship for thermal engineering / computer-based planning takes over the part of the thermal energy efficiency of a holistic view. The use of potential synergy effects of electrical energy efficiency is pushed forward by the professorship for electrical energy technology / regenerative energies. All professorships are characterized by preparatory work on the respective subject areas and can thus fall back on the necessary technological basics. The transfer of knowledge and results takes place both through the teaching on the training of highly innovative graduates and on the qualification of service providers of the Saxon economy within the emerging competence center. The research profile of the Westsächsische Hochschule Zwickau is sustained and strengthened externally. 


\section{Conclusion}

A central element in the publication and documentation of the results of the project, already mentioned in the first and second chapters, is the parallel construction of a new competence and demonstration center, which is economically independent from the project, but is interlinked with the project. To this end, an important step was taken in the Zwickau region four years ago with the founding of the Intelligente Infrastruktur Zwickau mbH. This created a political unique selling proposition feature. Large-scale tenants and the local energy provider put their interests back a bit, working together to find solutions to the major challenges faced by demographic trends in the future. With a competence center for "Affordable living in old age" as well as the development of new business processes for other economic stakeholders, the city of Zwickau is to become a leadership example for other cities in Germany, but especially in Saxony. The consideration of the topics of residential, health and energy supply costs happens interdisciplinary by different groups of interest. One of these interest groups is the Westsächsische Hochschule Zwickau, which is an important component of the transfer of knowledge and results in the research profile of energy efficiency. Thus, the sustainable use and documentation of the project results for the Zwickau region and its inhabitants can be ensured over the project duration. At the same time, the competence center plays an important role as a multiplier for supraregional actors in Saxony and beyond. Furthermore, the center of competence is the spatial basis for a possible spin-off of some of the scientists. It is also planned to publish the results of the project on a common internet platform in order to make the results available to a broad public [10]. At the end of the project, the project results are also planned to be presented in a book.

The reference to the principles of environmental protection and resource protection has already been clarified in the previous chapters of this paper. Furthermore, the integration of demographic aspects in the development of the social innovation content of the project is enhanced. In addition there is a close co-operation with the "Social Affairs and Projects" department of the Verband sächsische Wohnungsbaugenossenschaften e.V. (Association of Saxon Housing Cooperatives), which analyzes the compatibility of the results for tenants and landlords. The consideration of so-called "ethical, legal and social implications" - also called ELSI aspects - makes an important contribution to the safeguarding of basic questions of equality, equal opportunities and non-discrimination as well as in particular data protection and safeguarding the personality rights in this sensitive environment of the tenants. For this purpose, a subcontractor is provided for monitoring the project with regard to these questions after the second and last project year. This has already been done in a similar way in previous research projects. In addition to the aforementioned cooperation in the course of the project, the planned project is supported by other stakeholders. Both the panel on climate issues of the city of Zwickau as well as the headquarters urban development of the Lord Mayor of Zwickau are involved. Last but not least, the project is also supported by the local energy supplier, Zwickauer Energieversorgung GmbH (ZEV).

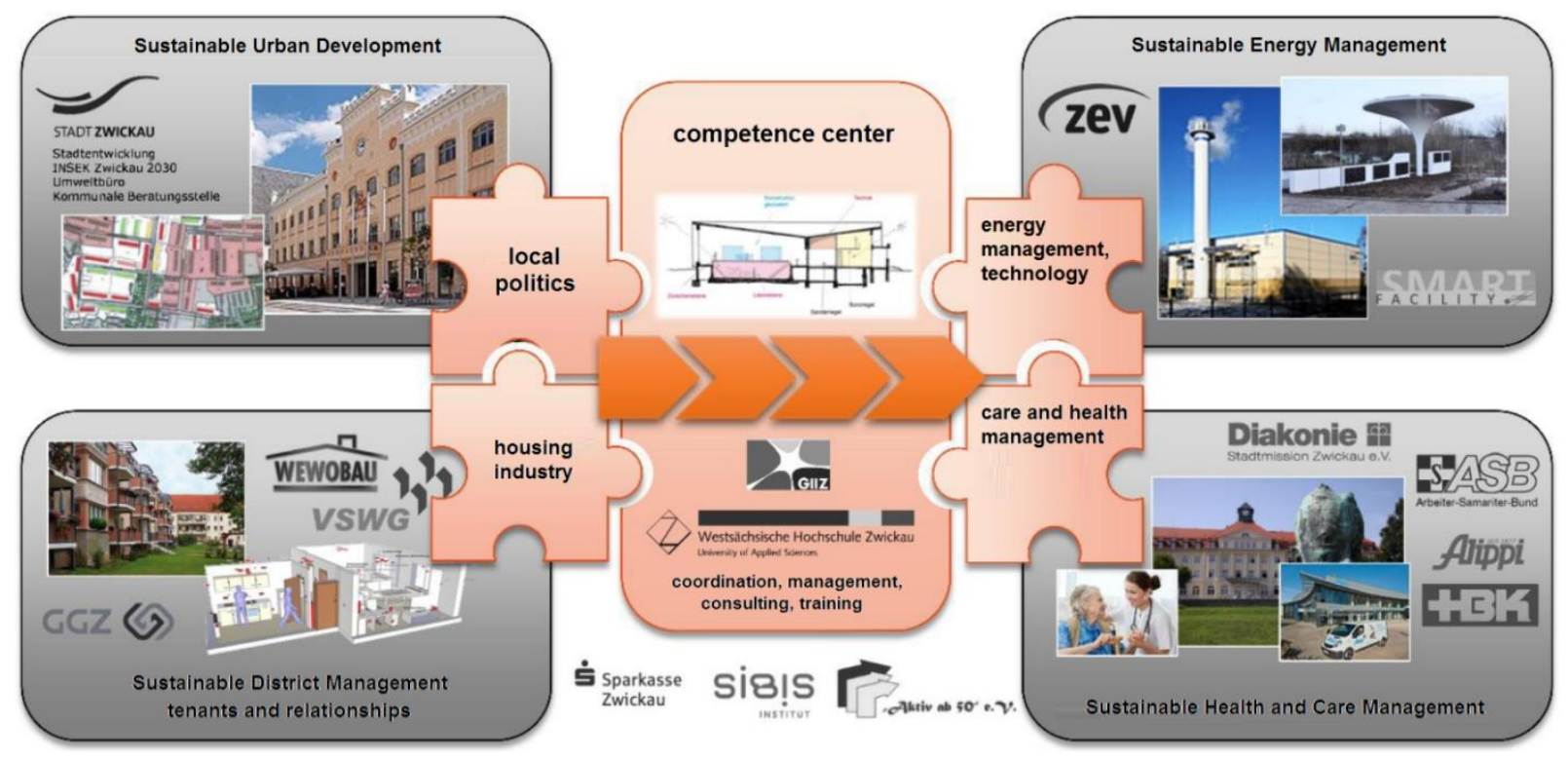

Fig. 4. Research and demonstration center

\section{Acknowledgments}

In the framework of the project, young scientists are primarily supported by the corresponding professors. During individual weekly workshops, current work progress is directly discussed and thus evaluated at all times during the project process. The professors ensure a correspondingly necessary cooperation, which is also reflected in the project calculation. In the regularly planned milestones, the entire research group meets for an interdisciplinary exchange of results together with representatives of the municipal workgroups of related topics. 
A number of cooperating practice partners are also taking part in these meetings. In doing so, particular attention is paid to existing and long-term successful cooperations with companies in the commercial sector or associations. This network is to be expanded by relevant partners within the framework of the project. As a result, several partners can contribute to project evaluation and profit from research results as well as the socially competent and professionally advanced employees of the research group. The influence of the cooperating partners will evaluate the results directly in terms of practicality and thus strengthen the application-oriented research of the young scientists. At the same time, these milestones represent a platform for the presentation of young scientists. This is an important component of personal development. In addition to this, the young researchers are themselves encouraged to ensure quality in research by ensuring transparency, application orientation and sustainability in the research work. The inclusion of tenants 'and senior citizens' representations has already provided a basis for ensuring the quality of the research work of young scholars and is also to be used in joint discussions during this project. As a further result of the preparatory work, the research group can draw on the knowledge and experience as well as the network of the municipal advisory center "Better life in old age through technology", a collaborative project between the city of Zwickau and thus further ensure the quality of the research results. After all we would like to thank all the partners who are part of the success of the project results for their commitment.

\section{References}

[1] van Bueren, E. M.; van Bohemen, H.; Itard, L. (2012); Visscher, H. (Eds.): Sustainable Urban Environments; Springer Verlag; ISBN 978-94-007-1294-2

[2] Raffelhüschen, B.; Müller Ch. (July 2011): Demografischer Wandel: Künftige Handlungsoptionen für die deutsche Rentenpolitik; Forschungsinstitut zur Zukunft der Arbeit; p. 4

[3] https://www.iwkoeln.de/themen/finanz-und-sozialpolitik/rentenversicherung; Accessed on: 2017-09-07

[4] Geyer, J.; Steiner V. (November 2010): Künftige Altersrenten in Deutschland: Relative Stabilität im Westen, starker Rückgang im Osten; Deutsches Institut für Wirtschaftsforschung; Wochenbericht; pp. 3 - 11

[5] IfD-Allensbach (2014), Kapitel „Von Altersarmut bis Verkehrsunfall“, p. 267; Forschung und Lehre; Deutscher Hochschulverband; Ausgabe 4, 21. Jahrgang; Bonn.

[6] T. Teich, S. Junghans, D. Kretz and M. Trommer (2016): "Non-Hierarchical Services Networks, steered by Competence Cells". B. Katalinic ed. DAAAM internati-onal Publishing, pp. 453.

[7] T. Teich, S. Wolf, S. Junghans, T. Neumann, S. Franke (2013): Concept for a service-oriented architecture in building automation systems. 24th DAAAM Interna-tional Symposium on Intelligent Manufacturing and Automation

[8] Teich, T.; Igel, W. (2010): Energieeffizienz in Wohngebäuden; GUC-Verlag; ISBN 978-3-934235-89-2

[9] Gentemann, R. B.; Schröder, F.; Teich T. (August 2012): Smart Metering belegt Energieeinsparung - Geniax System im Mietwohnungsbau; in: HLH Bd. 63 Nr. 8, Springer-VDI-Verlag, Düsseldorf, pp. 83-87

[10] http://ubineum.de/home.html; ; Accessed on: 2017-09-12 